\title{
Cell free HIV-1 virus can infect inner and outer foreskin polarized explants
}

\author{
MP Lemos ${ }^{1 *}$, ML Perez $^{1}$, J Sanchez ${ }^{2}$, J Lama ${ }^{2}$, S Montano $^{3}$, J McElrath ${ }^{1}$ \\ From AIDS Vaccine 2012 \\ Boston, MA, USA. 9-12 September 2012
}

\section{Background}

In sexually insertive men, HIV is predominantly transmitted at the penile surface. We report two mayor advances in the study of HIV infections at the foreskin.

\section{Methods}

First, we have developed cryopreservation methods that allow infection of foreskin tissue explants after thawing $(654+/-178.3 \mathrm{pg}$ of $\mathrm{p} 24 / \mathrm{gr}$ of tissue) and provide comparable infection rates to fresh samples( $716.5+/-446 \mathrm{pg}$ of p24/gr of tissue). Second, we have developed an ex vivo assay that uses human foreskin explants to replicate the polarized viral entry. After $12 \mathrm{~h}$ of polarized exposure, HIV entering the explant is amplified for 6 days of culture with activated PBMCs and measured using p24 ELISA.

\section{Results}

Preserving the epithelial barriers, we show that polarized infections permit the entry and expansion of less virus $(68.28+/-10.65 \mathrm{pg}$ of $\mathrm{p} 24 / \mathrm{gr}$ of tissue) than non-polarized infections $(650.4+/-205.9 \mathrm{pg}$ of $\mathrm{p} 24 / \mathrm{gr}$ of tissue) where the virus can enter the $\mathrm{CD} 4 \mathrm{~T}$ cell rich epidermal-dermal interface $(\mathrm{p}=0.04)$. Using 10000 TCID50 of HIV-1Bal per explants, we can detect infection in 100\% of the non-polarized assays and $69 \%$ of the polarized explants. Lastly, comparing foreskin tissue from 4 donors, we demonstrate that the inner and outer foreskin are both equally able to support cell-free HIV infection in polarized assays (inner $77.67+/-64.7$ vs. outer $92.82+/-66.81 \mathrm{pg}$ p $24 / \mathrm{gr}$ of tissue $\mathrm{p}=0.369)$ and in nonpolarized assays (inner $730.9+/-323.7$ vs. outer $625+$ / 301.2pg p24/gr of tissue $\mathrm{p}=0.41$ ).

'Fred Hutchinson Cancer Research Center, Seattle, WA, USA

Full list of author information is available at the end of the article

\section{Conclusion}

We hope that this approach could be used efficiently as a model to evaluate the efficacy of prevention strategies.

\section{Author details}

'Fred Hutchinson Cancer Research Center, Seattle, WA, USA. ${ }^{2}$ IMPACTA, Lima, Peru. ${ }^{3}$ Naval Medical Research Unit 6, Lima, Peru.

Published: 13 September 2012

doi:10.1186/1742-4690-9-S2-022

Cite this article as: Lemos et al: Cell free HIV-1 virus can infect inner and outer foreskin polarized explants. Retrovirology 2012 9(Suppl 2):O22.
Submit your next manuscript to BioMed Central and take full advantage of:

- Convenient online submission

- Thorough peer review

- No space constraints or color figure charges

- Immediate publication on acceptance

- Inclusion in PubMed, CAS, Scopus and Google Scholar

- Research which is freely available for redistribution
() Biomed Central 